\title{
M-GAM MODEL BASED EVALUATION OF GRADAC RIVER GORGE FOR GEOTOURISM DEVELOPMENT
}

\author{
Jelena Milenkovićc ${ }^{*}$, \\ Milica Lukić1, \\ Jelena Milovanović \\ 1 University of Belgrade - \\ Faculty of Geography, \\ Belgrade, Serbia \\ 2Singidunum University, \\ Belgrade, Serbia
}

\begin{abstract}
:
The results obtained through evaluation of the Gradac River Gorge by applying the M-GAM model are presented in this study. The main goal of the research was to observe current state and explore possibilities for geotourism development in this area. By virtue of numerous indicators and sub-indicators, which are categorized either in group of Main or Additional values, this methodology gives us good insight in potentials of geoturism development. In addition, the methodology has been improved by involving tourists. This approach offers a more objective perspective of the needs of tourists and provides a starting point for further research. Recently, Serbia has been included in UNESCO's Global Geopark Network due to the Djerdap Gorge being made the country's first geopark. The Gradac Gorge is equally valuable; it has vast geoheritage, extraordinarylandscapes, lush vegetation, and rich cultural and historical heritage. The geomorphological uniqueness of Gradac is the distinct meandering of the lower part of the river valley. Considering that it's also a protected area (a Landscape of Outstanding Features), a valuable fishing area, and one of the most important tourist sites in Valjevo Region, it has high potential to become one of Serbia's future Geoparks. The obtained results show the gorge having exceptional potential for geotourism development. On the other hand, it's necessary to improve the guide service, the visitor center, and more additional values.
\end{abstract}

Keywords:

Geotourism, M-GAM model, evaluation, geoheritage, Gradac River Gorge.

\section{INTRODUCTION}

Given the existing problems in the global environment and the great pressures that civilization puts on nature, one of the components of the natural heritage deserves more and more attention. It's a geoheritage (Arrad et al., 2020). This has been proven by the increase in the number of studies conducted worldwide (Arrad et al., 2020; Gray, 2019; Li et al., 2018; Lima et al., 2010; Nazaruddin, 2020; Plyusnina et al., 2016). In his study, Nazaruddin (2020) highlighted that geoheritage covers different geodiversity elements with high values, such as scientific, educational, aesthetic, recreational, cultural, etc. On the foundation of geoheritage, in the early 1990s, a new concept of tourism was introduced, named "geotourism". It is a form of tourism that focuses on geology, landscapes, and geoeducation (Arrad et al., 2020; Dowling and Newsome, 2006; Hose, 2008; Tičar et al., 2018; Tomić et al., 2020).
Correspondence:

Jelena Milenković

e-mail:

e-n-n-a@live.com 
Hose (1995) has defined geotourism as providing abilities or skills which can help tourists to better understand what actually means "geosites", its genesis, different types, natural and ecological values, etc. Significance of the geoheritage and numerous benefits of geotourism for society are recognized by two international programs of relevance to geoconservation - World Heritage Sites and Global Geoparks, and both of them are promoted by UNESCO (Gray, 2019). According to Gray (2019) three main reasons of Global Geoparks establishment are "conservation of geoheritage, geological education, and sustainable economic development mostly through geotourism".

Tomić et al. (2020) highlighted that the geodiversity of Serbia is very diverse and represents one of the important natural resources. The Institute for Nature Conservation of Serbia, which represents the most significant institution on the national level in this area, has recognized the necessity for legal protection of geoheritage; therefore, today there are around 80 protected geoheritage sites in Serbia (Djurović and Mijović, 2006). In addition, modern society becomes aware of the risks posed by mass tourism and relies more on individual and collective responsibility to protect the environment (Lukić and Filipović, 2019). Tourism based on ecologically responsible behavior, where the main touristic motive is the natural and cultural heritage, like geotourism, many domestic and regional experts see as a possibility for future tourism development in our country. That is the main reason why the issue of geotourism and geoheritage in Serbia has become the subject of several studies and projects (Antić et al., 2019; Božić et al., 2014; Božić and Tomić, 2015; Boškov et al., 2015; Tomić and Božić, 2014; Tomić et al., 2020, Vujičić et al., 2011).

The main goal of this paper is the evaluation of the Gradac river's gorge by applying the M-GAM model (Modified Geosite Assessment Model), in order to observe its current state and explore possibilities for geotourism development. In recent years, Serbia's geoheritage was evaluated through the mentioned model on several occasions. After the GAM model was introduced by Vujičić et al. in 2011, it has been modified and improved into the M-GAM model by Tomić and Božić (2014). So far, studies involving this assessment method have resulted in a number of useful conclusions and valuable results. For instance, Tomić and Božić (2014) have applied M-GAM to evaluate the Lazar Canyon area, located in Eastern Serbia. In addition, Božić et al. (2014) have conducted a comparative analysis of Lazar and Uvac Canyons. Božić and Tomić (2015) have examined two different tourist perspectives on selected two canyons (Lazar Canyon and Uvac Canyon) and two gorges (Ovčar-Kablar Gorge and Djerdap Gorge) as good representatives of the geomorphological heritage. Regarding main and additional values in that study, the Djerdap Gorge was rated with the highest values. Incredible landscapes and the extraordinary geoheritage of the Djerdap Gorge and its hinterland, as the longest gorge in Europe, were the main reasons why UNESCO listed this gorge as a Global Geopark in July 2020. The proclamation of the first geopark in Serbia will enable the promotion of our country in a new light. Given the significant natural geodiversity of Serbia, it is not impossible to expect future proclamations of new geoparks. Furthermore, Tomić et al. (2020) have explored the potential for the development of geotourism in the Danube Region of Serbia, based on 9 geosites in this area. Eastern Serbia was the study area once more when Antić et al. in 2019 have analyzed karst geoheritage and geotourism potential in the Pek River lower basin. The quality of this methodology was also recognized in some EU countries, so for the first time, it was applied in Slovenia for the purposes of speleotourism, by Tičar et al. in 2018.

\section{STUDY AREA}

The Gradac River, a tributary of the Kolubara River, flows through the area in the western part of Serbia called the "Valjevska-podgorina Region". As a result of specific geological characteristics of the terrain and different geomorphological processes, in the area of the Lelić and Valjevo karst, a deep gorge, almost $23 \mathrm{~km}$ long, was formed (Institute for Nature Conservation of Serbia, 2020). The Gradac river's gorge is one of the most attractive areas in this part of Serbia. Landscape characteristics are reflected primarily in the geomorphological features of the gorge. The main characteristic is the pronounced meandering of the lower part of the valley. The trapped meander curves, with the opposite ranging limestone meander promontories up to $60 \mathrm{~m}$ high, have in some places narrowed the valley bottom to only $5 \mathrm{~m}$. The depth of the gorge is between 150 to $300 \mathrm{~m}$. In addition to the typical limestone cliff ornamentation, represented by steep, jagged faults and talus slopes, the sides of the valley are carved with a combination of dry valleys, gullies, and ravines. 
The landscape dynamics are additionally complicated by dry valleys with sinkholes, deep and short valleys of many side tributaries of the Gradac River, numerous caves, pits, abysses, springs, alluvial terraces and cascades over which Gradac flows (Institute for Nature Conservation of Serbia, 2020; Simić, 2008).

Although it is placed in the close surrounding of the city of Valjevo, the center of the Kolubara district, the area of the gorge has managed to withstand anthropogenic pressures to the greatest extent and to preserve its high ecological value. Since 2001, it has been protected as a "Landscape of Outstanding Features", according to the Decision on the Designation of the Landscape of Outstanding Features "Gradac River Gorge", by the Municipal Assembly of Valjevo (Official Gazette of the Municipality of Valjevo, No. 1/2001). According to the Spatial Plan of the City of Valjevo (2013), the gorge is classified as a PBA area (Prime Butterfly Areas), and also as a potential area of international importance for biodiversity conservation, i.e. it is part of Emerald Network of Areas of Special Conservation Interest (ASCI). Furthermore, it is an area with a larger number of habitats of protected and strictly protected plant species of national importance -371 plant species have been registered here.

Figure 1. Gradac River Gorge - 1) Monastery Ćelije, 2) Church of St. Arhangel Mihailo and Gavrilo, 3) Monastery Lelić, 4) Degurić Cave, 5) Jerina’s Town
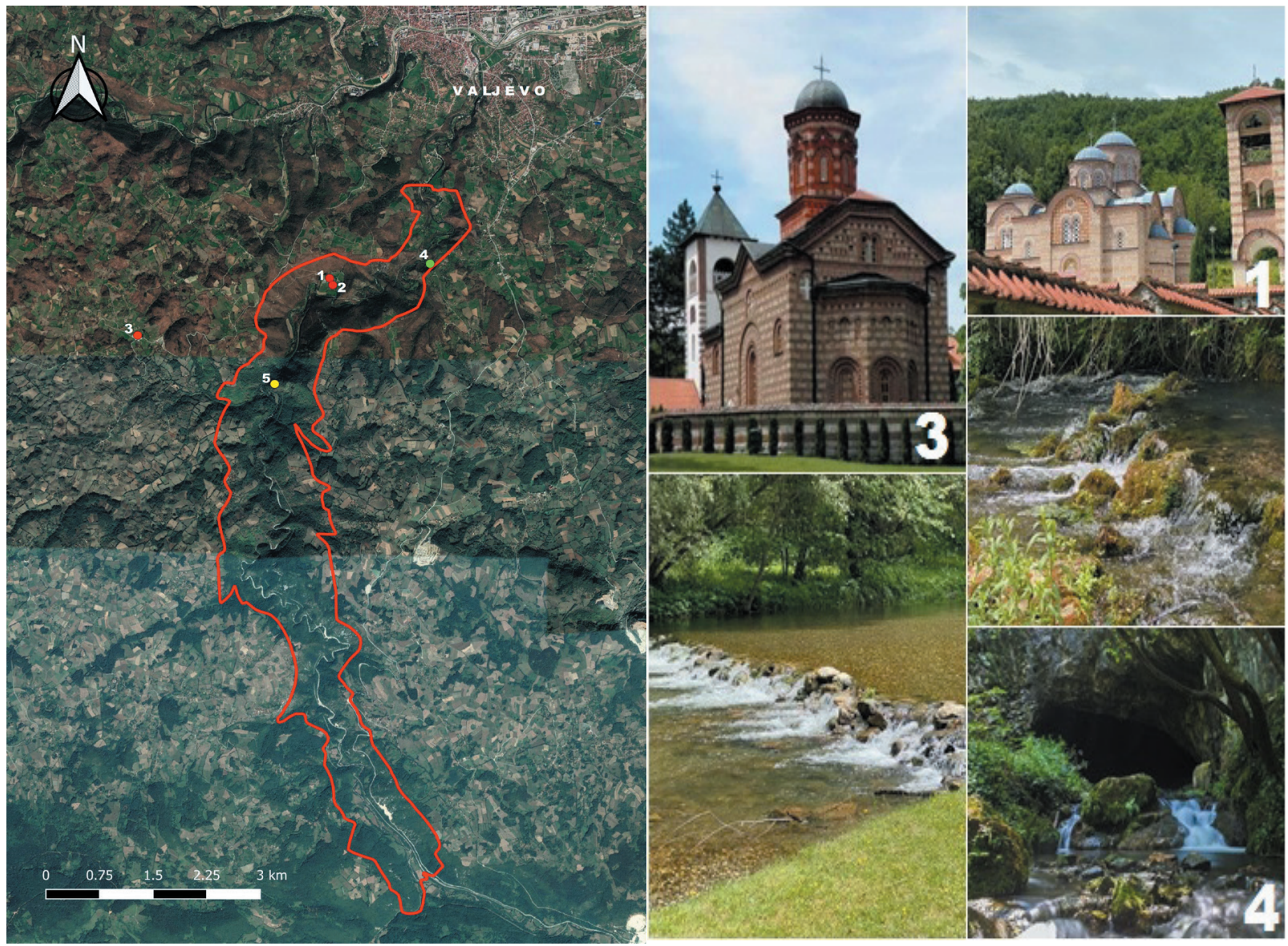

Source: Authors' pictures

\section{METHODOLOGY}

The assessment of geosite values and its current conditions is mandatory so as to identify the potential for geotourism development (Boškov et al., 2015). For evaluating the Gradac river's gorge, this paper uses a model called Modified Geosite Assessment which was designed by Tomić and Božić (2014). It's based on the Geosite Assessment Model (GAM) (Table I) which was created by Vujičić et al. (2011). 
In the GAM, the grades for each sub-indicator are given by experts but the Modified Geosite Assessment Model (M-GAM) takes into account these grades along with the importance of each sub-indicator (which is based on tourists' opinions). This leads to more reliable and accurate results (Tomić and Božić, 2014). The M-GAM is divided into two groups of indicators: Main Values (MV) and Additional Values (AV). The Main Values are further divided into three indicator sub-groups: Scientific/Educational Value (VSE), Landscape/ Aesthetic Value (VSA), and Protection (Vpr) (thereby forming a total of 12 sub-indicators). The Additional Values are divided into two indicator sub-groups: Functional Values (VFn) and Tourist Value (Vtr) (thereby forming a total of 15 sub-indicators - shown in Table 1) (Tomić and Božić, 2014). All sub-indicators are rated by experts and tourists with ranges from 0.00 to 1.00 (Table 2). The M-GAM is obtained by adding the Main and Additional values: $\mathrm{M}-\mathrm{GAM}=\mathrm{MV}+\mathrm{AV}$. The Main Values are obtained by adding three indicators $(\mathrm{MV}=\mathrm{VSE}+\mathrm{VSa}+\mathrm{Vpr})$ while the Additional Values are obtained by adding two indicators $(\mathrm{AV}=\mathrm{VFr}+\mathrm{VTr})$ (Tomić and Božić, 2014).

In the M-GAM, tourists take part in the assessment process via a survey that asks them to rate the importance (Im) of all 27 sub-indicators $(0.00,0.25,0.50,0.75,1.00)$ (Tomić and Božić, 2014). Once all the ratings are collected, each sub-indicator's average value is determined and its final value is the importance factor (Im). Then the product of the importance factor $(\mathrm{Im})$ and the value determined by experts $(0.00,0.25,0.50,0.75,1.00)$ is derived (Tomić and Božić, 2014).

The M-GAM equation is defined as:

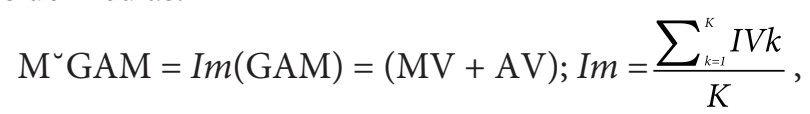

$I V k$ represents the assessment of each sub-indicator by a particular visitor and $K$ indicates the total number of visitors. Im values can be between zero and one (inclusive) (Tomić and Božić, 2014).

The research conducted by Božić and Tomić (2015) divided geotourists into 2 categories: general and pure. Pure geotourists were defined as people whose main reason for visiting is related to the geological and geomorphological processes that influenced geosite creation. Generally, geologists, geomorphologists, and people with a deep interest in and knowledge of geology are considered pure geotourists. General geotourists were defined as those who, instead of being motivated by the geological significance of a geosite, are just interested in its additional natural and aesthetic values or are just curious about it and the activities they can do there. In their paper, Božić and Tomić (2015) determined the importance factor $(\mathrm{Im})$ for both pure and general geotourists and that these values can be used universal factors in other research. 


\section{-}

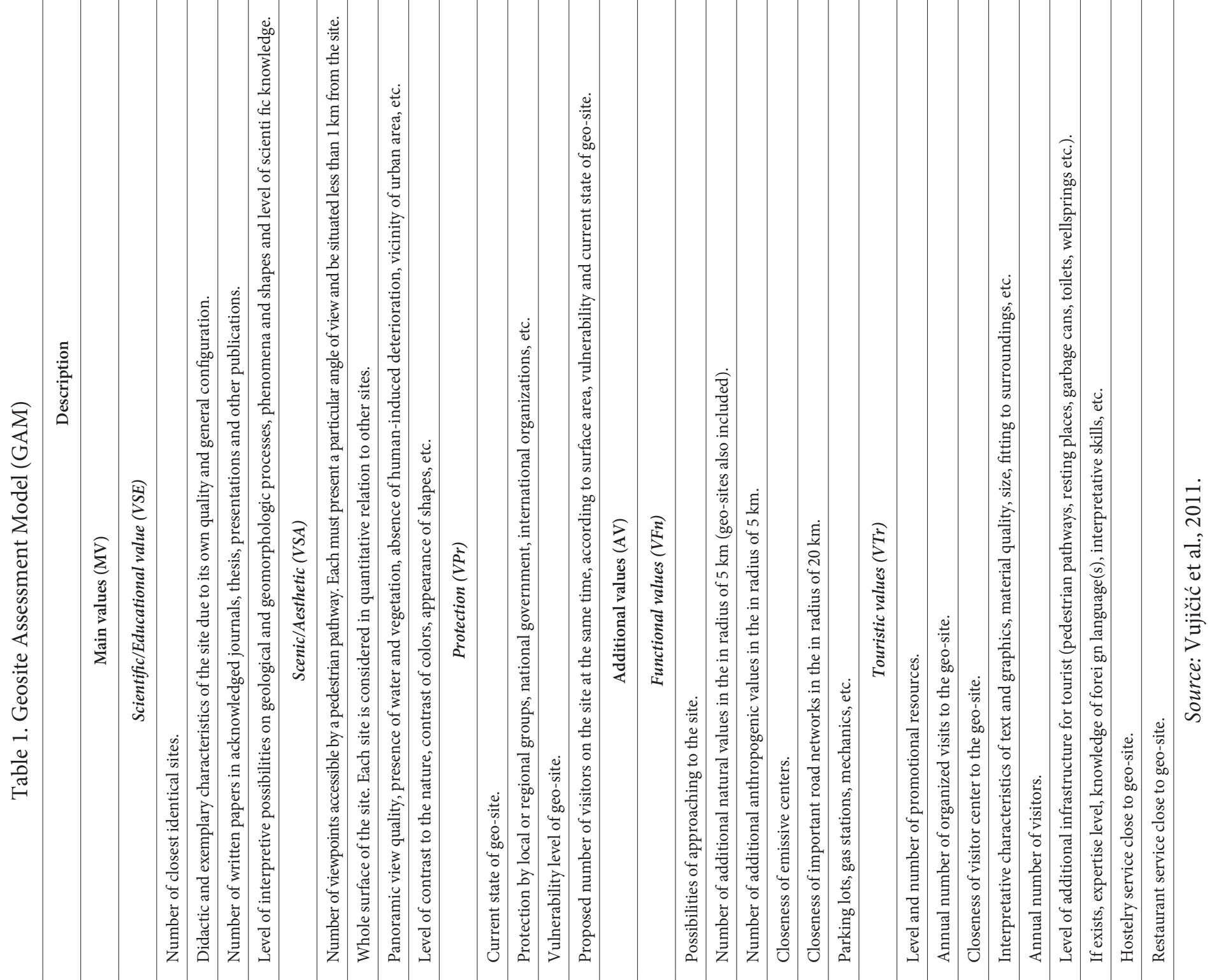

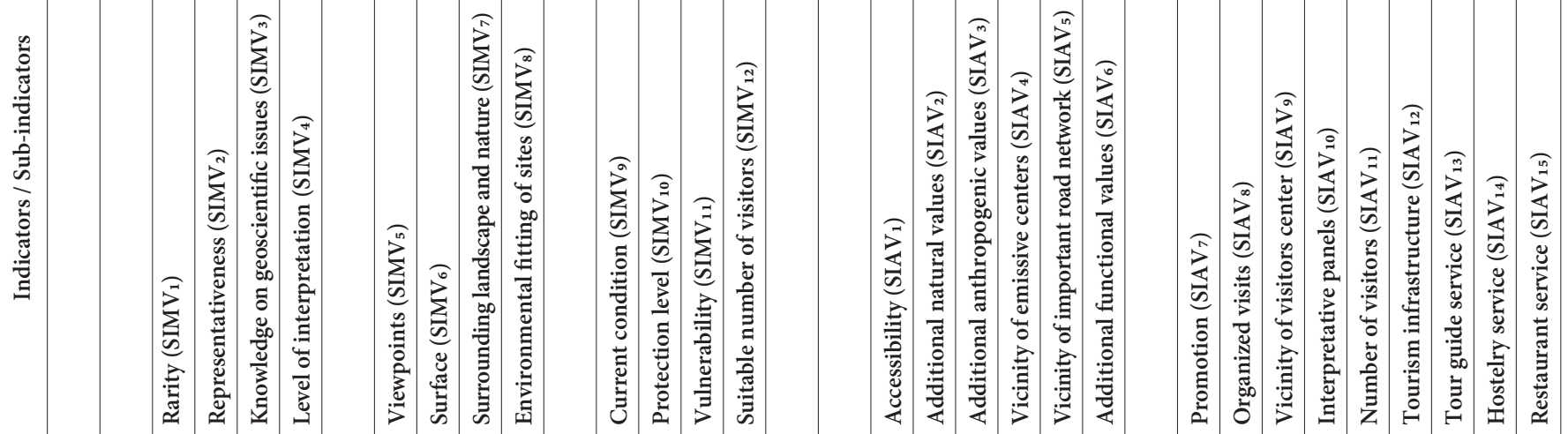




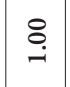

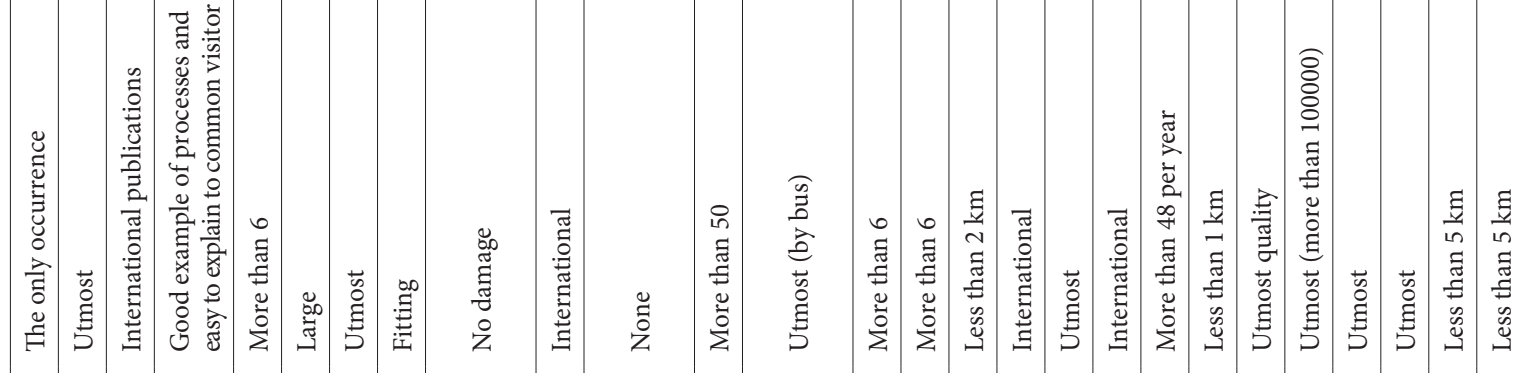

$\stackrel{10}{\circ}$

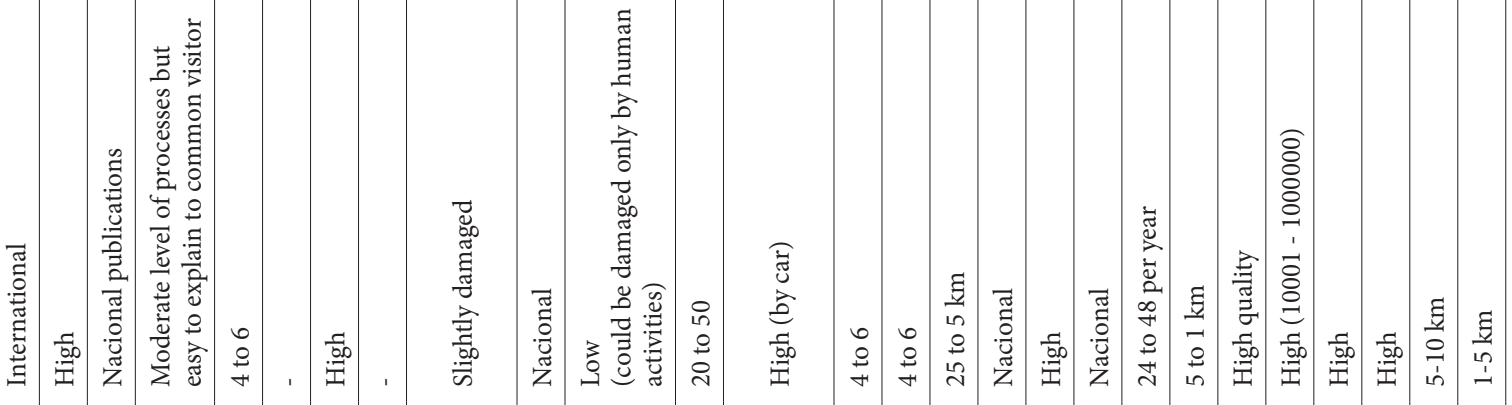

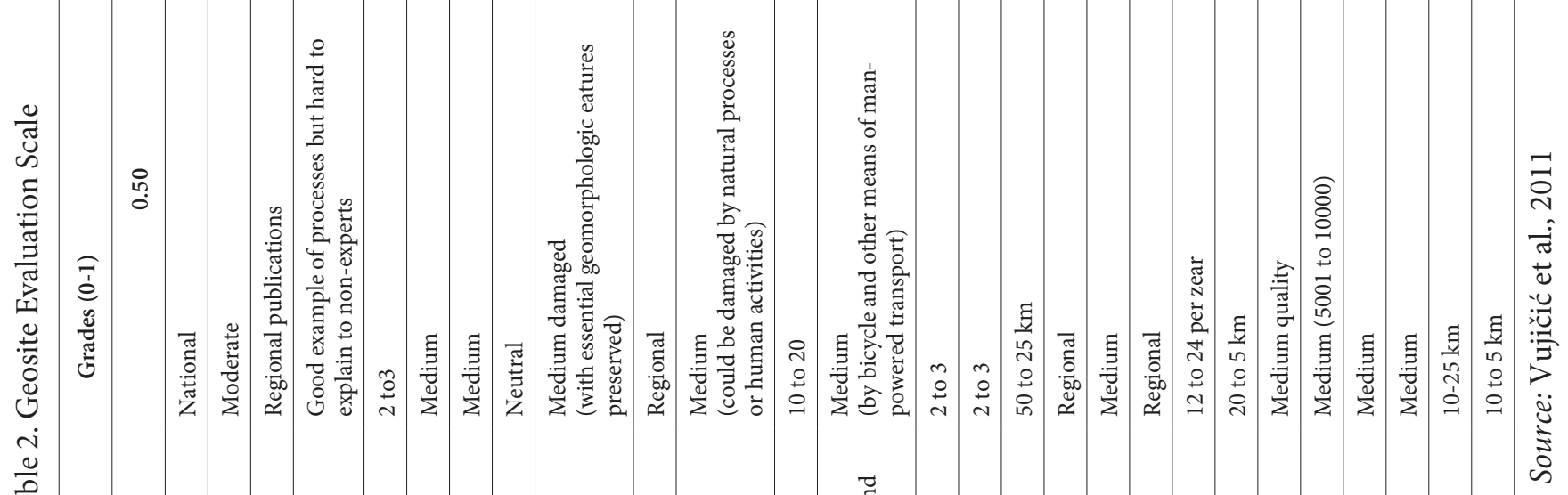

$\stackrel{\dddot{2}}{3}$

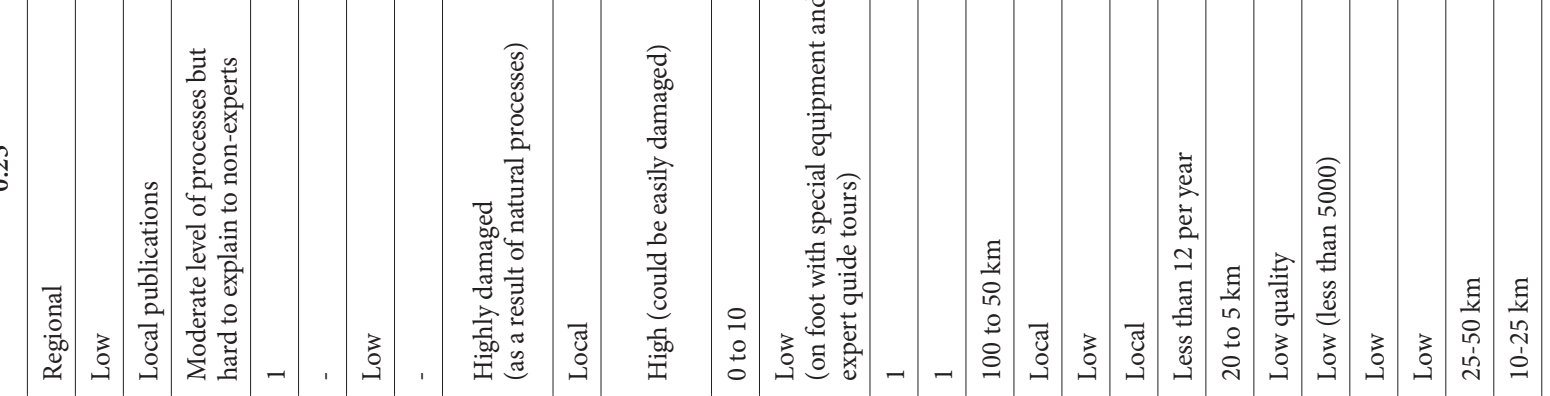

$\%$

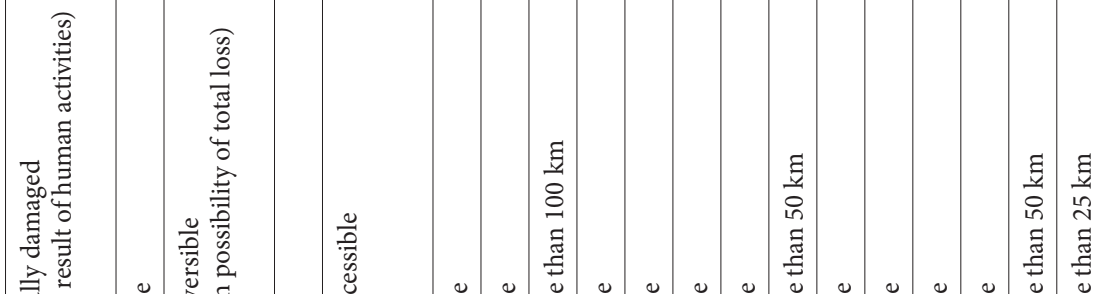

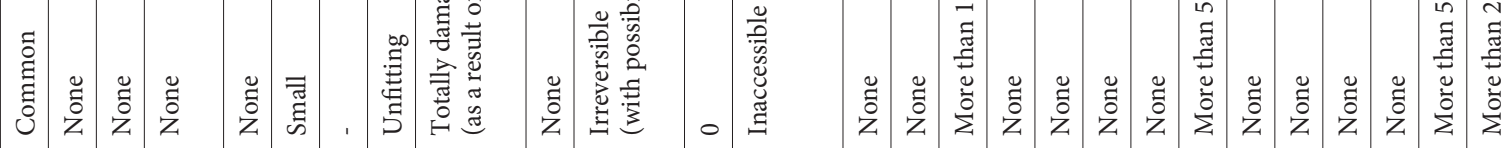

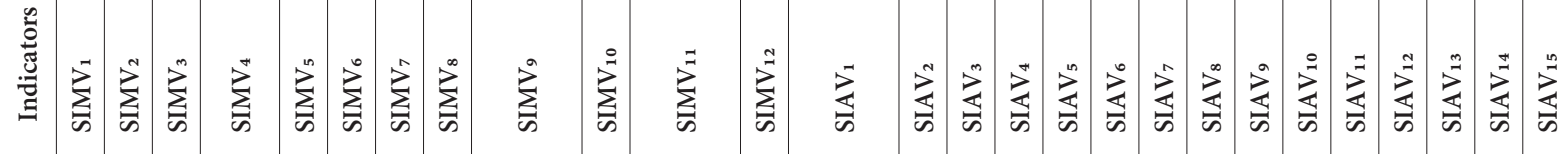




\section{RESULTS AND DISCUSSION}

In order to evaluate the potential of the Gradac river's gorge with respect to geotourism development, the M-GAM model was used. Unlike the proposed importance factor ( $\mathrm{Im}$ ) by Božić and Tomić (2015), which can be applied for other geosites research, as a universal factor, we went a step further and determined the importance factor $(I m)$ for the subject of our research - the Gradac river's gorge (Table 3). Table 3 is derived based on the methodology developed by Tomić and Božić (2014) and represents values given by experts and importance factor given by pure geotourists for the Gradac river's gorge. The survey was conducted in August 2020. The questionnaire consisted of 27 sub-indicators, and the respondents were asked to rate the importance (Im) for each particular sub-indicator. The rating was done using a scale from zero to one $(0.00,0.25,0.50$, $0.75,1.00$ ), where 0 is the lowest value and 1 is the highest value. The target group were tourists who are well acquainted with the researched area. They spend a lot of time in nature, preserve and nurture its values, and have prior knowledge of geology and geomorphology. The questionnaire was completed by 57 respondents who meet the stated criteria and are considered as pure geotourists (Božić and Tomić, 2015). The research results show that the Gradac river's gorge has medium Main and Additional Values, which classified the gorge into the $\mathrm{Z}_{22}$ cell (Table 4, Fig. 2).

Gorges are a common occurrence in the mountainous part of Serbia but not all gorges have the same significance from the aspect of scientific/educational values. The Gradac river's gorge can't be observed in isolation from the area in which it developed. It's considered as a whole of united geological, geomorphological, hydrological, and biogeographical features. Due to its attractive geomorphological characteristics of relief, hydrogeological features, habitats of rare and endangered plant and animal species, complex forest ecosystems and cultural values, the Gradac river's gorge is protected as a Landscape of Outstanding Features (Institute for Nature Conservation of Serbia, 2020). Geomorphological peculiarity is seen in the form of a pronounced meandering of the valley's lower part. The river valley is characterized by the appearance of clamped meanders and meandering limestone capes, while the sides of the gorge are steep, often very vertical (Simić, 2008). 


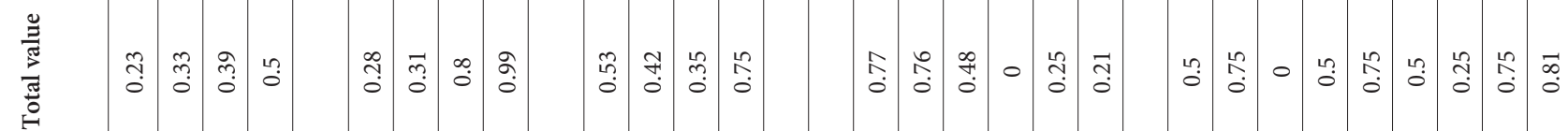

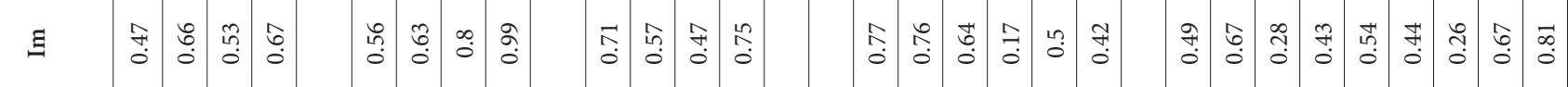
究

0
0
0
0
0
0
0
0
0
0

$\stackrel{\Xi}{\Xi}$

官

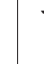

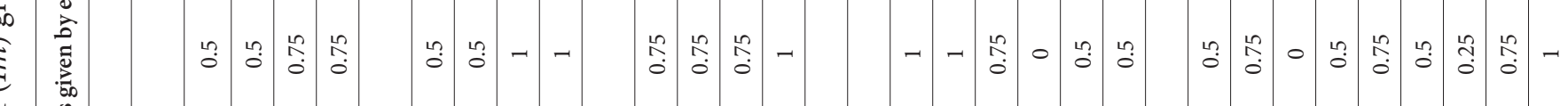

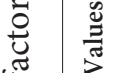

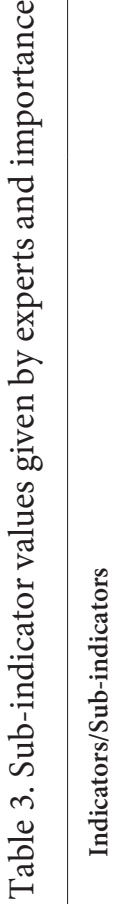

을

繁

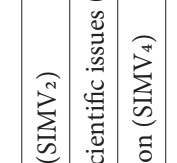

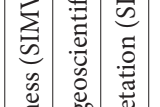

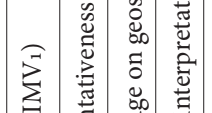

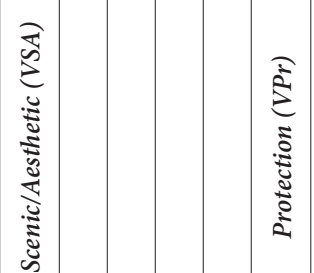

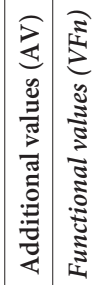

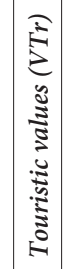


The scientific community has always been interested in researching this area, and as a result, today we can find numerous scientific papers that analyze the Gradac river's gorge from different aspects. Most research has been presented through regional publications. Researchers are highly educated individuals living near the gorge. However, given that the significance of the gorge exceeds the regional level, the interest of the scientific community is national, and there are many national publications (Krpo-Ćetković et al., 2019; Marković et al., 2015; Matić et al., 2007; Simić, 2008; Vasović, 2003; Virijević-Jovanović and Pijevac, 2018). The potential for geotourism development is observed through the possibilities of interpreting geosites as well. The Gradac river's gorge has a moderate level of the geological process which is easy to explain to a common visitor. This indicates that the geosite can be presented to tourists of different profiles and interests.

The Gradac river's gorge is one of the most attractive and best preserved ambient landscapes in this part of Serbia (Matić et al., 2007). Protection, conservation, and management activities of this geosite are entrusted to a non-governmental organization - Ecological Society "Gradac" from Valjevo. The gorge is protected at the national level and it is a natural asset of great importance, which belongs to the II category of protection. A third level regime has been established, prohibiting activities that may endanger natural values (Institute for Nature Conservation of Serbia, 2020).

Thanks to geosite conservation activities, landscape/aesthetic values and protection (as an indicator of Main Values) were well evaluated. The Gradac river's gorge has several viewpoints from which geomorphological and hydrological phenomena can be observed. Most of the gorge is protected, and due to its surface, it can appease a larger number of visitors at the same time which will not endanger its current condition. Nevertheless, a slight damage to the geosite by the reckless behavior of visitors (mostly picnickers) was noticed. They impair aesthetic values and degrade the river's flow by dumping waste. Functional values are well assessed, which is in direct correlation with the proximity of the city of Valjevo, as a larger urban entity. Accessibility to the geosite is easy, allowing tourists to choose means of transportation. There is a significant number of speleological objects in the gorge, among which Degurićka, Kraljeva, Visoka, Baćina, and Gradska caves stand out. The gorge is a habitat of diverse flora and fauna. The river has first class water quality (Virijević-Jovanović and Pijevac, 2018). The importance of ichthyofauna is especially emphasized. The Gradac River is one of the richest fish stocks, not only in Serbia but also in the wider environment. In addition to numerous natural values, the Gradac river's gorge is a spiritual and cultural center. The Celije Monastery is located on the left side of the valley, in the area of the village of Lelić. The exact time of the monastery's establishment has not been determined. It is believed that it was built in the $13^{\text {th }}$ or $14^{\text {th }}$ century, during the reign of King Dragutin, i.e. Despot Stefan Lazarević. The relics of the Duke Ilija Birčanin, who was killed in the Slaughter of the Dukes (First Serbian Uprising) in 1804, and Justin Popović, doctor of theology and professor at the University of Belgrade, rest in the monastery complex (Matić et al., 2007). Among other cultural values, the medieval fortress "Jerina’s Town", Ilovačića watermill, and hydroelectric power plant Degurić stand out. Although it is not located in the gorge itself, the Lelić Monastery should be singled out. It's a little more than $5 \mathrm{~km}$ away from the Celije Monastery. The monastery is the endowment of Bishop Nikolaj and his father Dragomir Velimirović. The relics of Bishop Nikolaj were transferred from America in 1991 and are now in the nave of the Lelić Monastery (Matić et al., 2007).

Table 4. The overall ranking of the Gradac River Gorge by the M-GAM

\begin{tabular}{|c|c|c|c|c|c|}
\hline Geosite name & \multicolumn{2}{|c|}{ Main Values } & \multicolumn{2}{|c|}{ Additional Values } & Field \\
\hline \multirow{2}{*}{ Gradac Gorge } & $\mathrm{VSE}+\mathrm{VSA}+\mathrm{VPr}$ & $\sum$ & $\mathrm{VFn}+\mathrm{VTr}$ & $\sum$ & \multirow{2}{*}{$\mathrm{Z}_{22}$} \\
\hline & $1.45+2.38+2.05$ & 5.88 & $2.47+2.94$ & 5.41 & \\
\hline
\end{tabular}

Source: Authors

Promotion is mainly carried out at the regional level. The gorge is known to the population of the surrounding settlements. The exceptions are mountaineers and nature lovers. Promotional activities, that are in the domain of the work of the Tourist Organization of Valjevo, is necessary to be improved and modernized. The Gradac river's gorge has between 24 and 48 organized visits annually. Most of them are organized by mountaineering associations, and a smaller part are school and student excursions. A considerable number of individual visits were noticed. Therefore, the number of visitors annually ranges between 10,000 and 100,000. 
Interpretive panels are of medium quality. They fit well into the environment and are well designed but it is necessary to increase their number along the river. It is suggested that each set of interpretive panels inform the visitors about the different values of the gorge. This would give visitors a better understanding of the importance of the geosite. The Gradac river's gorge doesn't have a visitor center nor a tour guide service. The tour guide service is available only for organized visits, which are previously announced to the Tourist Organization of Valjevo or the Ecological Society "Gradac". This is considered a major drawback. Efforts should be directed towards organizing a visitor center, where tourists could get information about the geosite. On the other hand, it is necessary to organize a tour guide service that would be available to every individual who decides to visit Gradac river's gorge. There are hiking trails and resting places in the gorge. The importance of the gorge is evidenced by the fact that the section of the Europe's walking trails - E7 passes through it (Spatial Plan of the City of Valjevo, 2013), as one of the two sections that pass through Serbia. ${ }^{1}$ However, garbage cans are rare along hiking and mountaineering trails (mostly located near the Ćelije Monastery), while toilets and other tourist infrastructure facilities do not exist. Due to the immediate vicinity of the city of Valjevo, there is a large number of accommodation and restaurant services. There is a lack of accommodation services in the immediate vicinity of the river flow, the respondents' state. This may be in conflict with nature protection but choosing accommodation facilities that use alternative energy sources for their operation and are based on sustainable business could be an acceptable solution. Another proposed solution it is to map and arrange additional trails for tourists and visitors that will allow easier and faster movement through the gorge thereby making different parts of this area more accessible.

Božić and Tomić (2015) explored the potentials for geotourism development in the gorges (Djerdap Gorge and Ovčar-Kablar Gorge) and canyons (Lazar Canyon and Uvac Canyon), through the comparative analysis from two perspectives of geotourists: general and pure. The research results of pure geotourists classified the Djerdap Gorge in the $Z_{22}$ cell, indicating medium Main and Additional Values, which matches the Gradac river's gorge. However, although they are in the same cell $\left(\mathrm{Z}_{22}\right)$, differences in the Main Values are evident. The Djerdap Gorge has a value of 7.98 (Gradac 5.88) which makes it on the border with high Main Values. Such results are not surprising considering that the Djerdap Gorge was recently inscribed in the UNESCO list of Global Geoparks and was declared the first geopark in the territory of the Republic of Serbia. Also, it was once again confirmed that its importance exceeds national borders. In addition, the Djerdap Gorge is one of the largest protected natural assets in Serbia $(63,786.48 \mathrm{ha})$. Due to its size and dominant geomorphological and hydrological forms of relief, it attracts the attention of not only pure geotourists, but also general. In terms of Additional Values, the Gradac river's gorge (5.41) is better positioned in relation to the Djerdap Gorge (5.3). This is because the Gradac river's gorge is located in the immediate vicinity of a larger city settlement - Valjevo - thereby enabling good traffic connections and various accommodation and restaurant services.

Figure 2. Position of Gradac Gorge (black) and Djerdap Gorge (blue) in the M-GAM matrix

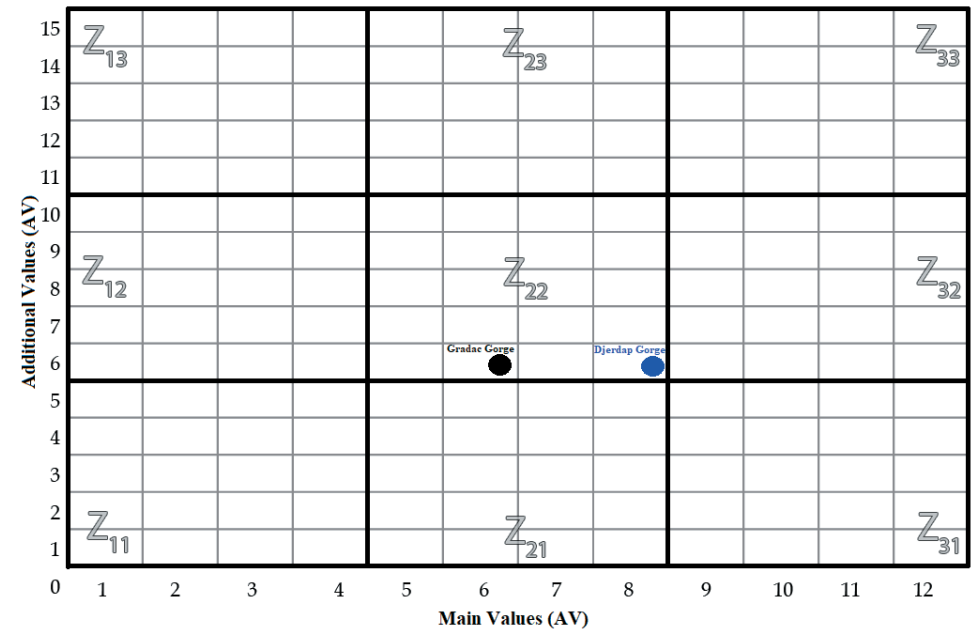

1 The European Ramblers' Association (ERA) brings together 63 walking organizations from 33 European countries. These organizations have a total of more than 3 million individual members. The association has designed 12 European paths whose total length exceeds $55,000 \mathrm{~km}$. Two European paths pass through Serbia - E4 (Eastern Serbia) and E7 (Western Serbia) (European Ramblers Association, 2020). 


\section{CONCLUSION}

Due to its natural and anthropogenic values, as the basis for the tourism development in the broadest sense, the Gradac river's gorge has exceptional potential. Natural values have emerged as a result of many years of endogenous and exogenous processes and they can't be visibly changed in the near future. Additional values are mostly in the domain of human activities, which means that the idea, organization, strategy, and development plans and their implementation can enrich natural values in order to develop geotourism. Geotourism is a type of tourism that relies on sustainable tourism development. This means that geosites are valued for the needs of tourism in order to provide socio-economic benefits, while conserving natural heritage, respecting the sociocultural authenticity of local communities, and ensuring tourist satisfaction. For geotourism development of the Gradac river's gorge, it is proposed:

- Establishment of a visitor center in which tourists will get acquainted with the basic values of geosites, and comprehensive information on the rules of behavior in nature. The center should also monitor tourist flow.

- Organizing a tour guide service that will be available to individual and group visits. The tour guide service should lead tourists on trails that are exclusively intended for them, with the provision of all necessary information about the geosite. Tour guides should know at least one foreign language.

- Setting up interpretive panels along the trails intended for tourists, which will be designed to inform tourists about certain geosite values (geological, geomorphological, speleological, hydrological, climatological, biogeographical, and cultural). Each interpretive panel should contain patterns of responsible behavior for tourists.

- Setting up garbage cans along trails for tourists.

- Charging parking fees. The collected money should be purposefully used for the functioning of the Ecological Society "Gradac".

- Establishment of punitive measures for irresponsible behavior of tourists, which impair the basic and aesthetic values of the Gradac river's gorge.

- Providing financial resources for more efficient functioning of the Ecological Society "Gradac" so that a sufficient number of rangers (due to lack of financial resources currently only 1 or 2 people are in charge) who would take into account the rules of behavior of visitors and punish irresponsible tourists.

- Construction of eco-lodges that are in accordance with the principles of environmental protection (use of sustainable and renewable energy sources, adequate treatment of garbage and wastewater, implementation of environmental education programs for employees, tourists and locals, etc.). ${ }^{2}$

- Organizing interactive workshops for tourists of different profiles and ages.

- Improving the availability of the Ecological Society "Gradac" (reactivation of the website and enabling correspondence by phone and e-mail in order to obtain information on speleology, flora and fauna, fishing, tourist attractions, etc.).

Through the conducted research, we have determined that the Gradac river's gorge has an exceptional potential for geotourism development but there is a lot of room for the improvement of Additional Values. It is necessary to design and direct an offer that will be adapted to different types of tourists and not just geotourists. This is important to emphasize because geotourists have an increased level of awareness of the importance of preserving natural and cultural values. General tourists on the other hand, can leave long-term negative consequences and degrade the geosite because of their reckless behavior. In addition, to ensure adequate geotourism development, it is necessary to improve cooperation between the public and private sectors, which is currently at a low level. It is also necessary to improve and modernize promotional activities and expand them to the national level. The Tourist Organization of Valjevo has a crucial role in that because it represents the tourist values of Valjevo (to which the Gradac river's gorge territorially belongs) on the domestic and international tourism market.

2 Eco-lodges and eco-tents are smaller and modest accommodation facilities, located within a protected natural asset or in the immediate vicinity, designed to fit into the natural environment. They are made of environmentally friendly materials, which function using renewable energy sources (Gardner, 2001). 
Better organization of the website (containing more information about the Gradac river's gorge, its natural and cultural values, emphasizing the importance of responsible behavior) could directly and indirectly influence tourists and their behavior in the future.

Thus, tourism and environmental protection would be in less conflict and the development of geotourism could help not only to increase the employment of the local population, but also to increase their awareness of preserving geosites. With an approach that integrates organization of geotourism and its responsible management, a number of positive effects could be expected in the future.

\section{ACKNOWLEDGMENT}

The paper represents the results of research on the National project supported by the Ministry of Education, Science and Technological Development, the Republic of Serbia (No. 176008), and according to the Agreement of Cooperation No. 0801-417/1 (21/03/2019).

\section{REFERENCES}

Antić, A., Tomić, A., \& Marković, S. (2019). Karst Geoheritage and Geotourism Potential in the Pek River Lower Basin (Eastern Serbia). Geographica Pannonica, 23(1), 32-46, DOI: 10.5937/gp23-20463.

Arrad, Y.T., Errami, E., Ennih, N., Ouajhain, B., Ettachfini, E.M., \& Bouaouda, S.M. (2020). From geoheritage inventory to geoeducation and geotourism implications: Insight from Jbel Amsittene (Essaouira province, Morocco). Journal of African Earth Sciences, 161, 103656, DOI: 10.1016/j.jafrearsci.2019.103656.

Božić, S., Tomić, N., \& Pavić, D. (2014). Canyons as potential geotourism attractions of Serbia - comparative analysis of Lazar and Uvac canyons by using M-GAM model. Acta Geoturistica, 5(2), 18-30.

Božić, S., \& Tomić, N. (2015). Canyons and gorges as potential geotourism destinations in Serbia: comparative analysis from two perspectives - general geotourists' and pure geotourists'. Open Geosciences, 7(1), 531-549. DOI: 10.1515/geo-2015-0040.

Boškov, J., Kotrla, S., Jovanović, M., Tomić, N., Lukić, T., \& Rvović, T. (2015). Application of the Preliminary Geosite Assessment Model (GAM): The Case of the Bela Crkva Municipality (Vojvodina, North Serbia). Geographica Pannonica, 19(3), 146-152, DOI: 10.5937/GeoPan1503146B.

Decision on the Designation of the Landscape of Outstanding Features "Gradac river gorge" (Official Gazette of the Municipality of Valjevo, No. 1/2001).

Djurović, P., \& Mijović, D. (2006). Geoheritage of Serbia - Representative of its total geodiversity. Collection of papers - Faculty of Geography, University of Belgrade, 54, 5-18.

Dowling, R., \& Newsome, D., (2010). Geotourism: a global activity. In: Dowling, R., Newsome, D. (Eds.), Global Geotourism Perspectives. Goodfellow Publishers, Woodeaton, 1-17.

European Ramblers Association. (2020, August). E-Paths. Retrieved August 25, 2020, from http://www. era-ewv-ferp.com/era

Gardner, J. (2001). Accommodations. Encyclopedia of Ecotourism. CABI Publishing, pp. 525-534.

Gray, M. (2019). Geodiversity, geoheritage and geoconservation for society. International Journal of Geoheritage and Parks, 7, 226-236. DOI: 10.1016/j.ijgeop.2019.11.001.

Hose, T.A. (1995). Selling the story of Britain's stone. Env. Interpret, 10(2), 16-17.

Hose, T.A. (2008). Towards a history of geotourism: definitions, antecedents and the future. In: The History of Geoconservation, Vol. 300, 37-60, Geological society, special publication.

Institute for Nature Conservation of Serbia. (2020, March). Central Register of Protected Natural Resources. Retrieved August 17, 2020, from http://www.zzps.rs/wp/centralni-registar/?lang=en; http://www.zzps. $\mathrm{rs} / \mathrm{wp} / \mathrm{gradac} /$ ?lang=en

Krpo-Ćetković, J., Subotić, S., Skorić, S., \& Ćirković, D. (2019). Diet of the Eurasian otter (Lutra lutra) on the River Gradac, Serbia: Predation in a brown trout-dominated stream. Aquatic Conservation; Marine and Freshwater Ecosystems, 29(2), 282-291. DOI: 10.1002/aqc.3013.

Li, Y., Chen, S., \& Li., Y. (2018). The evaluation and development of the geoheritage landscapes in Dalian Jinshitan National Marine Park. International Journal of Geoheritage and Parks, 6(1), 63-74. DOI: 10.17149/ ijg.j.issn.2210.3382.2018.01.005. 
Lima, F.F., Brilha, J., \& Salamuni, E., (2010). Inventorying geological heritage in large territories: a methodological proposal applied to Brazil. Geoheritage, 2(3), 91-99. DOI: 10.1007/s12371-010-0014-9.

Lukić, M., \& Filipović, D. (2019). Landscape evaluation for the purposes of ecotourism - case study of Burgenland. In the $27^{\text {th }}$ International Conference Ecological Truth and Environmental Research - EcoTER'19, 18-21 June 2019 (pp. 511-518). Bor, Serbia: University of Belgrade - Technical Faculty in Bor.

Matić, V., Janićević, S., \& Čerović, S. (2007). The cultural inheritance of the river Gradac in the role of tourism development in the area of Valjevo. Geographica Pannonica 11, 65-69. DOI: 10.5937/GeoPan0711065M.

Marković et al. (2015). Ecological status assessment of the Gradac River (Western Serbia) based on aquatic macroinvertebrates. In Third Symposium of Biologists and Ecologists of Republic of Srpska, 12-14 November 2015, (pp. 157-162). Banja Luka, Republic of Srpska: University of Banja Luka.

Nazaruddin, A.D. (2020). Granite landforms of Samui Island (southern Thailand) from geoheritage, geoconservation and geotourism perspectives. International Journal of Geoheritage and Parks, 8, 75-86. DOI: 10.1016/j.ijgeop.2020.05.003.

Plyusnina, E.E., Sallam, E.S., \& Ruban, D.A. (2016). Geological heritage of the Bahariya and Farafra oases, the central Western Desert, Egypt. Journal of African Earth Sciences, 116, 151-159. DOI: 10.1016/j.jafrearsci.2016.01.002.

Simić, S. (2008). Waters of Valjevo's Kolubara - an integral part of protected natural areas. Journal of Nature Conservation 58(1-2), 53-71.

Spatial Plan of the City of Valjevo (2013). Belgrade, Serbia: Institute of architecture, urban and spatial planning of Serbia.

Tičar, J., Tomić, N., Breg Valjavec, M., Zorn, M., Marković, B.S., \& Gavrilov, B.M. (2018). Speleotourism in Slovenia: balancing between mass tourism and geoheritage protection. Open Geoscience, 10, 344-357, DOI: 10.1515/geo-2018-0027.

Tomić, N., \& Božić, S. (2014). A modified Geosite Assessment Model (M-GAM) and its Application on the Lazar Canyon area (Serbia). Int. J. Environ. Res., 8(4), 1041-1052.

Tomić, N., Marković, B.S., Antić, A., \& Tešić, D. (2020). Exploring the potential for geotourism development in the Danube region of Serbia. International Journal of Geoheritage and Parks, 8, 123-139. DOI: 10.1016/j. ijgeop.2020.05.001.

Vasović, M. (2003). Podrinje-Valjevo Mountains. Valjevo: Agency Valjevac.

Virijević-Jovanović, S., \& Pijevac, V. (2018). Tourism in fuction of sustainable development of the Gradac River in Serbia. In The third international scientific conference, tourism in function of development of the Republic of Serbia - tourism in the era of digital transformation, 31 May - 1 June 2018 (pp. 416-433). Vrnjačka Banja, Serbia: Faculty of hotel management and tourism in Vrnjačka Banja.

Vujičić, D.M., Vasiljević, A.Đ., Marković, B.S., Hose, A.T., Lukić, T., Hadžić, O., \& Janićević, S. (2011). Preliminary Geosite Assessment Model (GAM) and its application on Fruška gora mountain, potential geotourism destination of Serbia. Acta geographica Slovenica, 51(2), 361-377. DOI: 10.3986/AGS51303. 